\title{
Indicators of Work Accidents in Slaughter Refrigerators and Broiler Processing
}

\section{-Author(s)}

\section{Takeda F'}

Moro ARPI

Machado L

Zanella $A L^{\prime}$

Universidade Federal de Santa Catarina UFSC.

\section{Mail Address}

Corresponding author e-mail address Fabiano Takeda

Rua Aristides Lobo, 340 - apto 304, Agronômica, Florianópolis, SC, Zip code: 88025510, Brasil.

Tel: $\quad$ (48) 996967366

Email: takeda.f@bol.com.br

\section{EKeywords}

Animal welfare; Behavioral trait; Genetic parameters; Survival kit; Wild birds.

\section{ABSTRACT}

This research aims at describing data for an epidemiological profile, as well as to contribute to the improvement of systems of information, prevention and risk control of accidents in the workplace in processing and further processing broiler plants. In this study, data from documents of 1,274 investigations of typical work accidents were analyzed. Descriptive statistics were used for the analysis, and the frequency and severity of accidents were calculated according to NBR 14280:2001. The results show that men tend to have more accidents than women; $69.8 \%$ of those injured had been in the company for less than 3 years; $37 \%$ of the accidents were cuts; $35.6 \%$ were bruises; the most affected body parts were hands and fingers, representing a total of $48 \%$ of all accidents; $41.6 \%$ of victims were not using personal protective equipment (PPE) at the time of the accident; the underlying causative condition of $54.9 \%$ of the accidents was the lack of personal safety. The proportion for each accident with leave was 1.7 accidents without leave but with a need for relocation of activity and 10.9 accidents without leave without relocation. There were amputation cases among some of those given leave of absence. For every million hours worked, there were 3.2 accidents with leave and 139.4 days of absence were registered. The study concludes that accident rates in in processing and further processing broiler plants are high, and that it is extremely important to establish an epidemiological profile in order to guide prevention and control actions.

\section{INTRODUCTION}

The meat processing and further-processing industries currently make of Brazil one of the world's leading exporters of animal products (Marra et al., 2013). The production volume and the number of companies and employees of those industries have continuously grown worldwide, making significant contributions for the gross domestic product of many countries (IBGE, 2017; Barros \& Mendes, 2014). This growth is linked to the increasing global demand for animal protein, particularly for poultry meat, considering its healthy and affordable appeal (Harmse et al., 2016), which has also increased the pressure for competitiveness. Consequently, the animal industry activities have been become more intensive in the search for higher productivity and better quality of foods of animal origin. However, the physical and mental fatigue of the workers of the animal industry has increased, causing work accidents and occupational diseases.

Work accidents have always been an object of study because they are the main health problem suffered by workers worldwide (Bird, 1985). Contrary to the views of many, accidents do not occur by chance; instead, they are socially-determined, predictable, and preventable (Barros \& Mendes, 2014; Bird, 1985). 
The pig, poultry, and small-animal processing industry in Brazil recorded 6,760 accidents in 2011, 6,652 accidents in 2012, and 6,804 accidents in 2013, as listed by the National Classification of Economic Activities (CNAE $\left.{ }^{1}\right)$, number 1012-1, which the latest statistical yearbook on accidents, and available on the Social Security website of the Brazilian government. It should be noted that these data were compiled only from the typical accident indicators with an issued work accident report (CAT ${ }^{2}$ ) (INSS, 2017), and that there were no significant reductions in the number of accidents recorded during those three years.

Despite the high number of accidents in the meat processing and further-processing sector recorded by Social Security (INSS, 2017), several studies report that these numbers do not reflect the reality because many accidents are not duly reported. This lack of information limits the planning and implementation of policies for the prevention of work accidents. Official data on occupational accidents do not accurately show the results of accidents and mishaps if a CAT is not issued (Kearney, 2010; Tappin et al., 2008; Reardon \& Farina, 2010; Stearns et al., 1999).

Considering the demand for studies on occupational accidents, the frequency and the severity of accidents in the meat processing and further-processing industries, this study aimed at contributing to build an epidemiological profile of occupational accidents, as well as for the improvement of information systems, as well as the prevention and control of risks of occupational accidents with workers in the poultry processing and further-processing industries.

\section{MATERIAL AND METHODS}

According to methodological concepts, this is a cross-sectional case study carried out using secondary data obtained during the analysis of documents of work accident investigations (Yin, 2010). The study period was from January $1^{\text {st }}$ to December $31^{\text {st }}, 2016$.

Typical accidents described in accident-investigation documents were used in this study. Accidents were defined according to the internal safety and health management criteria of the company investigated, and not by the researchers, because the analyses were based on accidents previously characterized by the company and described in the documents. The following accident definitions were used: accident no

${ }^{1}$ Classificação Nacional de Atividades Econômicas.

${ }^{2}$ Comunicado de Acidente de Trabalho. leave and no need for activity relocation (ANL NR) defined as an accident that causes work disruption, but there is no labor capacity loss, and, according to the diagnosis of the medical staff, the individual continues to perform his/her usual activities during normal working hours; accidents no leave, but with activity relocation (ANL WR) - defined as an accident with a partial loss of labor capacity or in which the individual is relocated from his/her usual activities and does not need to leave the company; accidents with leave (AWL) - defined as those in which the injured person completely loses his/her labor capacity and is no longer able to perform his/her activities on temporary and/or permanent (invalidity) basis. According to the company's accident management flowchart, all accident victims are referred to the medical outpatient clinic of the plant, where they are initially cared by nurses who assess the need for referral to external care in hospitals and specialized clinics according to the injury and/or for examination by an occupationalhealth physician or general practitioner, who will determine if the injured person needs to be relieved or not from his/her activities and the treatment of the injury and record the accident type (ANL NR / ANL WR/ $\mathrm{AWL}$.

The objective of this study was to collect data to build an epidemiological profile of occupational accidents in order to contribute for improvement of information systems, and for the prevention and control of the risks of work accidents in broiler processing and furtherprocessing plants.

The inductive method was applied. The data available in the accident-investigation documents completed by the health and safety teams of the plants were surveyed for later theoretical formulation of the concepts that gave support to reach the proposed objectives (Lakatos \& Marconi, 2003).

The universe and sample consisted of 1,274 investigation reports on accidents in 10 broiler processing and further-processing plants belonging to a single company. Therefore, all plants applied the same methodology for the analysis and investigation of incidents and accidents. The 10 plants are located in the states of Paraná (2 sites), Santa Catarina (5 sites), and Rio Grande do Sul (3 sites). The total number of workers in the 10 locations is 15,165 , out of which 8,796 are women and 6,369 are men.

Data were collected from worksheets reporting work accidents in each plant. Data were analyzed and interpreted using descriptive statistics. 
The frequency and severity of incidents and accidents were calculated using the equations of NBR 14280:2001, as shown in Figure 1:

$$
\begin{gathered}
F R=\frac{N \times 1000}{M H T} \\
S R=\frac{T \times 1000}{M H T}
\end{gathered}
$$

Figure 1 -Equations used for the calculation of accident frequency rate (FR) and severity rate $(S R)$

Source: ABNT: NBR 14280:2001

Nomenclature: FR: accident frequency rate; N: number of accidents; MHT: number of man-hours duringan established time interval; SR: accident severity rate; and T: computed time (lost days)

The data and research protocol used in the present study were provided by the company. The study was approved by the Committee of Ethics in Research of the Federal University of Santa Catarina, and was in compliance with all legal requirements. The anonymity and confidentiality of information was maintained in the data records.

\section{RESULTS}

Table 1 shows the distribution of accidents with no leave and no need of activity relocation (ANL NR), accidents with no leave but with activity relocation (ANL WR), and accidents with leave (AWL), according to worker's gender, employment period, injury classification according to the accident investigation documents of each plant, affected body part, use of PPE, and cause.

The analyzed data included 1,021 accidents with no leave and no relocation (586 (ठ) and 435 (ㅇ))), 160 accidents with no leave and relocation $(106(\lambda)$ and 54 $($ ( ) )), and 93 accidents with leave longer than one day (75 ( $\left.{ }^{\Uparrow}\right)$ and $\left.18(9)\right)$, totaling 1,274 events (ANL NR / ANL WR / AWL).

The proportions of accidents involving men $(\lambda)$ and women $(q)$ in the studied plants were $57.4 \%(\hat{\delta})$ and $42.6 \%(q)$ for ANL NR, 66.3\% ( $\left.{ }^{\lambda}\right)$ and $33.8 \%(+)$ for ANL WR, and $80.6 \%$ (ठ) and $19.4 \%$ (क) for AWL.

Relative to employment period (months), the highest ANL NR proportion was $37.1 \%$ (up to 12 months), followed by $32.7 \%$ (12 to 36 months), and the lowest was $8.3 \%$ (>120 months). The highest ANL WR proportions were $28.1 \%$ (12 to 36 months) and $26.3 \%$ (up to 12 months), while the lowest was $13.8 \%$ (60 to 120 months). The highest proportion of AWL was $47.3 \%$ (up to 12 months) and the lowest was $7.5 \%$ (60 to 120 months) and 7.5\% (>120 months).
The injuries with the highest proportion in ANL NR were contusions (40.6\%) and small cuts (36.6\%), $50.0 \%$ cuts and $15 \%$ contusions in ANL WR, and $37 \%$ cuts and $35.5 \%$ contusions AWL.

The most affected body parts in ANL NR cases were hands and fingers (47.0\%), and head and neck (14.0\%). In ANL WR cases, $51.9 \%$ were injuries on hands and fingers, and $18.1 \%$ on the head and neck, while in AWL $48.0 \%$ of the injuries were on hands and fingers, and $14.1 \%$ on the head and neck.

The data collected from the accident investigation reports show that, in ANL NR, only $10.1 \%$ of those injured were not required to use PPE and that $41.2 \%$ were not using adequate PPE at the time of the accident. Proportions of $15.0 \%$ (PPE not applicable) and $44.4 \%$ (did not use PPE) were recorded in ANL WR cases, and $16.1 \%$ (PPE not applicable) and $40.9 \%$ (did not use PPE) in AWL.

According to accident investigation data, the results indicate that $57.4 \%$ of ANL NR occurred for reasons related to unsafe personal factors, while $45.6 \%$ of ANL WR and $43.0 \%$ of AWL were also related to the same factors.

Table 2 shows the accident stratification in each plant, as well as total days lost due to injury treatment. The number of workers per plant and the number of hours worked in 2016 are taken into account.

The average monthly number of workers was 15,165 , which corresponded to $28,633,361$ hours worked in 2016.

The overall monthly ratios among AWL, ANL WR, and ANL NR were 93:160:1021. This means that, in proportional terms, for each accident with leave, there were 1.7 accidents with no leave and need of activity relocation and 10.9 accidents with no leave and no need of activity relocation.

The total number of accidents with leave accounted for 3,992 lost work days of leave. Considering the average number of employees in each plant, this would mean that three production units (equivalent to units 6, 7 and 10) that stopped for one day due to the labor shortages caused by work accidents. It should be noted that the amputations were recorded as days lost only during the researched interval of 2016 , when there may be a longer interval the return of the worker.

Table 3 shows the results obtained for the frequency and severity rates of accidents.

The result shows there were 35.7 ANL NR, 5.6 ANL WR, and 3.2 AWL per million hours worked, and 139.4 days of leave of absence. 
Table 1 - Description of the results according to the type of accident registered.

\begin{tabular}{|c|c|c|c|c|c|c|c|c|}
\hline \multirow{2}{*}{ Characteristics } & \multicolumn{2}{|c|}{ ANL NR } & \multicolumn{2}{|c|}{ ANL WR } & \multicolumn{2}{|c|}{ AWL } & \multicolumn{2}{|c|}{ Total } \\
\hline & $\mathrm{n}$ & $\%$ & $n$ & $\%$ & $\mathrm{n}$ & $\%$ & $\mathrm{n}$ & $\%$ \\
\hline \multicolumn{9}{|l|}{ Sex } \\
\hline Male $(\overbrace{}^{\Uparrow})$ & 586 & 57.4 & 106 & 66.3 & 75 & 80.6 & 767 & 60.2 \\
\hline Female (ㅇ) & 435 & 42.6 & 54 & 33.8 & 18 & 19.4 & 507 & 39.8 \\
\hline \multicolumn{9}{|l|}{ Time of employment (months) } \\
\hline Up to 12 & 379 & 37.1 & 42 & 26.3 & 44 & 47.3 & 465 & 36.5 \\
\hline $12 \vdash 36$ & 334 & 32.7 & 45 & 28.1 & 21 & 22.6 & 400 & 31.4 \\
\hline $36 \vdash 60$ & 116 & 11.4 & 26 & 16.3 & 14 & 15.1 & 156 & 12.2 \\
\hline $60 \vdash 120$ & 107 & 10.5 & 22 & 13.8 & 7 & 7.5 & 136 & 10.7 \\
\hline$>120$ & 85 & 8.3 & 25 & 15.6 & 7 & 7.5 & 117 & 9.2 \\
\hline \multicolumn{9}{|l|}{ Type of injury } \\
\hline Cut & 374 & 36.6 & 80 & 50.0 & 17 & 18.3 & 471 & 37.0 \\
\hline Bruises & 415 & 40.6 & 24 & 15.0 & 15 & 16.1 & 454 & 35.6 \\
\hline Sprain & 56 & 5.5 & 7 & 4.4 & 7 & 7.5 & 70 & 5.5 \\
\hline Burns & 43 & 4.2 & 12 & 7.5 & 6 & 6.5 & 61 & 4.8 \\
\hline Amputations & 0 & 0.0 & 0 & 0.0 & 9 & 9.7 & 9 & 0.7 \\
\hline Fracture & 36 & 3.5 & 17 & 10.6 & 36 & 38.7 & 89 & 7,0 \\
\hline Intoxications & 35 & 3.4 & 8 & 5.0 & 0 & 0,0 & 43 & 3.4 \\
\hline Crushing & 7 & 0.7 & 2 & 1.3 & 0 & 0.0 & 9 & 0.7 \\
\hline Electric shock & 2 & 0.2 & 2 & 1.3 & 1 & 1.1 & 5 & 0.4 \\
\hline Eye soreness & 28 & 2.7 & 1 & 0.6 & 0 & 0.0 & 29 & 2.3 \\
\hline Skin soreness & 4 & 0.4 & 0 & 0.0 & 0 & 0.0 & 4 & 0.3 \\
\hline Respiratory irritation & 1 & 0.1 & 1 & 0.6 & 0 & 0.0 & 2 & 0.2 \\
\hline Dislocation & 4 & 0.4 & 5 & 3.1 & 2 & 2.2 & 11 & 0.9 \\
\hline Not informed & 16 & 1.6 & 1 & 0.6 & 0 & 0.0 & 17 & 1.3 \\
\hline Death & 0 & 0.0 & 0 & 0.0 & 0 & 0.0 & 0 & 0.0 \\
\hline \multicolumn{9}{|l|}{ Afflicted body part } \\
\hline Head and neck & 143 & 14.0 & 29 & 18.1 & 7 & 7.5 & 179 & 14.1 \\
\hline Thorax & 3 & 0.3 & 0 & 0.0 & 1 & 1.1 & 4 & 0.3 \\
\hline Abdomen & 3 & 0.3 & 2 & 1.3 & 0 & 0.0 & 5 & 0.4 \\
\hline Pelvis & 8 & 0.8 & 1 & 0.6 & 0 & 0.0 & 9 & 0.7 \\
\hline Back & 27 & 2.6 & 0 & 0.0 & 0 & 0.0 & 27 & 2.1 \\
\hline Lower limbs (leg, knee, ankles) & 138 & 13.5 & 13 & 8.1 & 11 & 11.8 & 162 & 12.7 \\
\hline Upper limbs (arms, forearms, fist) & 132 & 12.9 & 21 & 13.1 & 15 & 16.1 & 168 & 13.2 \\
\hline Hand and fingers & 480 & 47.0 & 83 & 51.9 & 48 & 51.6 & 611 & 48.0 \\
\hline Feet & 60 & 5.9 & 8 & 5.0 & 7 & 7.5 & 75 & 5.9 \\
\hline Several body parts & 27 & 2.6 & 3 & 1.9 & 4 & 4.3 & 34 & 2.7 \\
\hline \multicolumn{9}{|l|}{ Use of PPE } \\
\hline Yes & 497 & 48.7 & 65 & 40.6 & 40 & 43.0 & 602 & 47.3 \\
\hline No & 421 & 41.2 & 71 & 44.4 & 38 & 40.9 & 530 & 41.6 \\
\hline Does not apply & 103 & 10.1 & 24 & 15.0 & 15 & 16.1 & 142 & 11.1 \\
\hline \multicolumn{9}{|l|}{ Cause of accident } \\
\hline Unsafe condition & 282 & 27.6 & 36 & 22.5 & 35 & 37.6 & 353 & 27.7 \\
\hline Personal unsafety factor & 586 & 57.4 & 73 & 45.6 & 40 & 43.0 & 699 & 54.9 \\
\hline Personal condition and factor & 141 & 13.8 & 47 & 29.4 & 18 & 19.4 & 206 & 16.2 \\
\hline No characterization & 12 & 1.2 & 4 & 2.5 & 0 & 0.0 & 16 & 1.3 \\
\hline
\end{tabular}

Nomenclature: $n$ - number; ANL NR - accident no leave and no need for relocation of activity; ANL WR - accidents no leave but with relocation of activity; AWL - accidents with leave; PPE - personal protective equipment. 
Table 2 - Indicators for number of workers, hours worked, and days of leave by plant.

\begin{tabular}{lcccccccc}
\hline Plant & $\begin{array}{c}\text { Average number of } \\
\text { workers per month }\end{array}$ & $\begin{array}{c}\text { Number of workers } \\
\text { in a year }\end{array}$ & $\mathrm{H}$ in a year & ANL NR & ANL WR & AWL & TD & TD/T (\%) \\
\hline 1 & 1,918 & 23,012 & $3,674,316$ & 221 & 17 & 7 & 383 & 19.9 \\
2 & 1,142 & 13,701 & $2,057,926$ & 117 & 19 & 3 & 18 & 1.6 \\
3 & 1,901 & 22,812 & $3,729,158$ & 66 & 19 & 17 & 769 & 40.5 \\
\hline 4 & 1,672 & 20,059 & $3,056,372$ & 61 & 25 & 7 & 310 & 18.5 \\
5 & 1,812 & 21,745 & $3,471,958$ & 74 & 13 & 24 & 351 & 19.5 \\
6 & 1,329 & 15,950 & $2,478,898$ & 117 & 13 & 15 & 483 & 36.3 \\
7 & 1,218 & 14,617 & $2,249,258$ & 94 & 8 & 8 & 416 & 34.2 \\
8 & 1,524 & 18,289 & $2,891,496$ & 48 & 19 & 5 & 402 & 26.4 \\
9 & 1,438 & 17,252 & $2,650,156$ & 37 & 8 & 5 & 748 & 52.0 \\
10 & 1,212 & 14,540 & $2,373,823$ & 186 & 19 & 2 & 112 \\
\hline Total & 15,165 & 181,977 & $28,633,361$ & 1021 & 160 & 93 & 3992 \\
\hline
\end{tabular}

Nomenclatures: $\mathrm{H}$ - amount man-hours; ANL NR - accident no leave and no need for activity relocation; ANL WR - accidents no leave but with activity relocation; AWL - accidents with leave; TD - total days with leave; TD/T (\%)percentage of total days lost per average number of workers monthly.

Table 3 - Frequency and severity rates by plant.

\begin{tabular}{lcccc}
\hline Plant & FR ANL NR & FR ANL WR & GR AWL & GR \\
\hline 1 & 60.1 & 4.6 & 1.9 & 104.2 \\
2 & 56.9 & 9.2 & 1.5 & 8.7 \\
3 & 17.7 & 5.1 & 4.6 & 206.2 \\
4 & 20.0 & 8.2 & 2.3 & 101.4 \\
5 & 21.3 & 3.7 & 6.9 & 101.1 \\
6 & 47.2 & 5.2 & 6.1 & 194.8 \\
7 & 41.8 & 3.6 & 3.6 & 184.9 \\
8 & 16.6 & 6.6 & 1.7 & 139.0 \\
9 & 14.0 & 3.0 & 1.9 & 282.2 \\
10 & 78.4 & 8.0 & 0.8 & 47.2 \\
Total & 35.7 & 5.6 & 3.2 & 139.4 \\
\hline
\end{tabular}

Nomenclature: FR - Frequency rate and GR - gravity rate, ANL NR - accident no leave and no need for activity relocation; ANL WR - accidents no leave but with activity relocation; AWL - accidents with leave.

\section{DISCUSSION}

For the three criteria defined by the company and analyzed in the study (ANL NR: ANL WR: AWL), the proportion of injured males was higher (60.2\%). Similar results are reported in other studies conducted in slaughterhouses (Pegatin, 2009; Vasconcellos et al., 2009). It should be noted that in all 10 plants of the studied company, there were more female (58\%) than male $(42 \%)$ workers.

The number of accidents apparently reduced as the length of employment in the company increased; the shorter employment length, the higher the number of accidents. Out of the total number of workers, $67.9 \%$ (ANL NR: ANL WR: AWL) were injured when employed for than 36 months, and $47.3 \%$ of accidents with leave - the largest proportion - occurred when the workers were employed for 12 months or less. This is consistent with the finding of Vilela et al. (2012), who also found that the highest rates of accidents requiring leave happened within the first 12 months of employment, and recorded that the workers complained not having received proper training to safely carry out their activities, such as on the use of knives for carcass cut-up. Most accidents happen with less experienced workers (Araujo, 2008; Vilela et al., 2012). Studies in slaughterhouses in the USA indicate that workers receive little training and are often forced to work under the threat of dismissal if they refuse to work (Harmse et al., 2016; Human Rights Watch, 2004; Lipscomb et al., 2007).

The most common injuries among the three assessed criteria (ANL NR: ANL WR: AWL) were cuts and contusions. The body parts with the highest injury index were hands and fingers, which is consistent with other studies in slaughterhouses in Brazil and other countries, such as the USA, Portugal, New Zealand, Denmark, and Canada (Araújo, 2008; Buzanello \& Moro, 2012; Health \& Safety Executive, 2017; Musolin et al., 2013; Reis, 2012; Schulz et al., 2012; Thomsen et al., 2007; Vasconcellos et al., 2009).

Other authors attribute the high number of cut injuries to activities that require the use of knives and cutting equipment, such as saws and scissors, as well as to the strength and repetitive movement of the upper limbs, and to the workers' lack of training (Araújo, 2008; Buzanello \& Moro, 2012; Musolin et al., 2013; Schulz et al., 2012; Vilela et al., 2012).

It should also be noted that the accident investigation documents used in this study indicate that in $41.6 \%$ of accidents, workers were not using personal protective equipment at the time of the accident. This may be related to several factors, such as a failure to provide PPE, inadequate PPE, lack of training on the proper use of PPE, and/or worker behavior in terms of disregarding the risks they are exposed to when performing their activities (Araújo, 2008). 
In addition, Brazilian and international studies in slaughterhouses demonstrate that the speed of the processing lines is set according to the production process, regardless of worker capacity. This contributes to accidents that may occur when handling cutting equipment (Barros \& Mendes, 2014; Lipscomb et al., 2007; Vasconcellos et al., 2009).

Considering the need of using cutting equipment and the high rate of accidents (41.7\%) recorded because the workers were not using PPE at the time of the accident, there is a need to introduce new training methods of accident prevention, to determine criteria for the identification and control of occupational hazards, to carry out risk assessments of each job, considering the individual capacity of workers, and to provide training on the appropriate use of personal protective equipment, focusing on the development and improvement of a culture of work safety.

According to Table 1, among 1274 accident investigations, the unsafe personal factor accounted for the highest frequency of accidents, with $71.1 \%$ of the total.

As established in previous studies, a large proportion of the accidents are attributed to the unsafe personal factor, corresponding to about 70 to $80 \%$ of cases (Reason, 1990), in agreement with the results of the present study. However, stating that accidents occur due to personal recklessness is not sufficient to explain the causes of accidents at a level that can be used for organizational learning (Vilela et al., 2012). It should be kept in mind that human failure is the consequence and not the cause of the problem (Reason, 2002). A worker is influenced and provoked by factors concerning the work environment, and by organizational and managerial aspects (idem).

One of the options to diagnose the possible causes is to investigate accidents with the aim of understanding the possible determinants behind mishaps. The purpose of an investigation should not be to determine worker mistakes, but rather to understand the reasons why his/her actions or assessments made sense at the time of the accident (Dekker, 2002).

It is emphasized that accidents happen when a series of factors or causes converge under certain circumstances. There are only a few cases in which an accident or incident can be attributed to a single cause (Vilela et al., 2012). Companies and employees are generally aware of the factors and causes that lead to accidents.

Another important finding of the present study was that, for each accident resulting in registered leave, there were 1.7 accidents with no leave and need for activity relocation and 10.9 accidents with no leave and no need for activity relocation. This indicates that in the analyzed processing plants, accident distribution does not follow Frank Bird's pyramid theory, which is typically used to assess the probability of a possibly serious accident. This theory considers the ratio of $1: 10: 30: 600$, meaning that, for each serious accident, there are 10 minor ones, 30 with property loss and 600 minor accidents or near-miss accidents (Bird, 1985).

The analyses of the criteria of Frank Bird's pyramid and the results of the accident investigation documents show that the company's evaluation methodology is restricted to only two levels of the pyramid, which are major accidents and minor accidents, and that property damage and particularly near-misses, which theoretically are the base of the pyramid and the result of unsafe conditions, unsafe acts, and undesirable behaviors. The concept of Frank Bird's pyramid serves as a tool to analyze the risks and the prevention of accidents in a management system, aiming at the continuous improvement, minimization, and even elimination of unwanted events and their impacts. The lower in pyramid's base, the smaller are the chances of a major accident occurring (Bird, 1985).

In this context, statistically, in order to increase the possibilities of reducing accidents, especially those considered serious, it is essential to identify the data that compose the base of the accident pyramid, because only then it will be possible to propose actions to identify and control unsafe conditions and behaviors. It should be noted that, when identifying the causes of accidents in the present study, the causative condition of $71.1 \%$ of the accidents was attributed to the unsafe personal factor, which emphasizes the need to acknowledge the base of the pyramid.

Despite not following this theory, risk management becomes easier when an organization enters its own data and builds its own pyramid. Data are analyzed more easily and effectively and, more importantly, make sense to decision makers (Bird, 1985).

Considering the accident and incident frequency rates, for every million hours worked, rates of $\mathrm{AWL}$ : 3.2; ANL WR: 5.6 and ANL NR: 35.7 were calculated. These indicators can be used to control and to prevent accidents, as well as to compare companies of the same industry that have similar risk exposure, taking into account the time workers were exposed to risks $(\mathrm{H})$ and extrapolating the indicators to $1,000,000$ work hours. 
Overall, the results indicate that the number of accidents in the analyzed processing plants is high, considering the frequency and severity rates, and is mainly due to serious accidents resulting in amputations. According to a study carried out in the USA, the slaughter and broiler processing industries have the highest accident and disease rates, more than double the averages of manufacturing activities (Human Rights Watch, 2004; Linder, 1995). The high number of accidents seems to be characteristic of the slaughtering and meat processing industries and is a problem for slaughter companies and particularly for society as a whole, which highlights the need to establish mitigation actions to reduce accidents in this sector.

It should be noted that there were serious accidents requiring amputations that counted as days with leave (300 days in unit $1 ; 600$ days in unit $3 ; 100$ days in unit $5 ; 75$ days in unit $6 ; 60$ days in unit 8 ; and 600 days in unit 9). Major hazards are one of the main reasons for controlling less serious incidents and accidents, according to accident-control theories (Bird, 1985): the greater the control of "deviations" or "incidents", the greater the chances of controlling major accidents.

It is observed that the consequences of accidents are indeed comparable with theories that maintain that the damage caused affects the victims, companies, and society alike. The outcomes include amputations, absence of $26 \%$ of the workforce for a day in a year, and 3,992 days with leave (possible workers removed by INSS).

It should be pointed out that in the study of Vilela et al. (2012), published before the issue and mandatory implementation of NR 36, the same proportion of $26 \%$ of workers off work was diagnosed, a value similar to that obtained in this study in plants that had already implemented the compulsory actions on specific work health and safety in slaughter and meat-processing companies established in the NR 36 regulation (NR 36: 2014). This regulation of the Brazilian Ministry of Labor, issued on April 18, 2013, NR 36 establishes the minimum requirements for the evaluation, control, and monitoring of risks in the activities undertaken in meat processing plants for human consumption, aiming at ensuring permanent workplace safety, health, and quality of life at work, without prejudice to compliance with the provisions of the other regulations of the Ministry of Labor (NR 36: 2014).

The results of the present study showed that application of the NR 36 requisites have not yet reduced the percentage of absenteeism in the evaluated processing plants.
In summary, accident prevention is the key to the effective management of the health, safety, and environment of any organization. Understanding the indicators of undesirable events helps to prevent the recurrence of accidents in general and those with a greater impact on the physical integrity of workers.

There is limited research on accidents in meat processing plants, and most studies focus on ergonomics (Buzanello \& Moro, 2012; Santana, 2014; Vilela et al., 2012), despite the significant impact accidents have on this industry. Therefore, further research on the various risks involved in slaughter and meat-processing activities are needed to establish a corporate safety culture and to develop risk specific prevention tools (Harmse et al., 2016). In addition, such studies may aid the understanding the extent of risk exposure arising from those activities with the aim of maintaining workers' health and physical integrity, and of ensuring high productivity and a favorable perception of the meat-processing industry by the public.

\section{CONCLUSIONS}

The information obtained in the present study provides a diagnosis for managers, as well as health and safety prevention teams of meat-processing plants to allow them to act upon the causes of accidents, in addition to monitor and to compare indicators of accidents with no work leave in order to eliminate or to reduce the most frequent mishaps that require workers to be absent from work. This study aims at contributing to the current knowledge on this subject and at developing an epidemiological profile of occupational accidents in broiler processing and further-processing plants slaughterhouse and broiler processing industry that may aid to continuously improve working conditions.

\section{FUNDING}

This research did not receive any specific grant from funding agencies in the public, commercial, or not-forprofit sectors.

\section{ACKNOWLEDGEMENTS}

The authors acknowledge the work of the Safety and Medicine Service and the company's employees who contributed to this research, as well as the legal representatives of the company who allowed us to conduct this research. We would also like to thank the 
Takeda F, Moro ARP,

Machado L, Zanella AL
Indicators of Work Accidents in Slaughter

Refrigerators and Broiler Processing professors of the Production Engineering Department of the Federal University of Santa Catarina.

\section{REFERENCES}

ABTN - Associação Brasileira de Normas Técnicas. NBR 14280: cadastro de acidente do trabalho - Procedimento e classificação. Rio de Janeiro; 2001.

Araújo GCD, Gosling M. Gestão de acidentes de trabalho em uma empresa frigorífica: um estudo de caso. Revista Pretexto 2008;9(1):81-94.

Barros Oliveira PA, Mendes JMR. Processo de trabalho e condições de trabalho em frigoríficos de aves: relato de uma experiência de vigilância em saúde do trabalhador. Ciência \& Saúde Coletiva 2014;19(12):46274635.

Bird FE, Germain GL. Practical loss control leadership. Loganville: Institute Publishing; 1985

Buzanello MR, Moro AR. Increase of Brazilian productivity in the slaughterhouse sector: a review. Work 2012;41:5446-5448.

Dekker S. The field guide to human error investigations. $2^{\text {nd }}$ ed. London: Ashgate; 2002

Harmse JL, Engelbrecht JC, Bekker JL. The impact of physical and ergonomic hazards on poultry abattoir processing workers: a review. International Journal of Environmental Research and Public Health 2016;13(197).

Health \& Safety Excecutive. Statutory instruments owned and enforced by HSE/local authorities. 2017 [cited 2017 Mar 20]. Available from: http:// www.hse.gov.uk/legislation/statinstruments.htm

Human Rights Watch. Worker health and safety in the meat and poultry industry. New York; 2004 [cited 2017 Abr 10]. Available from: https:// www.hrw.org/reports/2005/usa0105/usa0105.pdf.

IBGE - Instituto Brasileiro de Geografia e Estatística. Base de dados agregados (SIDRA) Pesquisa Trimestral do Abate de Animais. Rio de Janeiro, 2017 [cited 2017 Abr 18]. Available from: http://www.sidra. ibge.gov.br/bda/tabela/listabl.asp?c=1093\&z=t\&o=24

INSS - Instituto Nacional do Seguro Nacional. Anuário Estatístico de Acidentes de Trabalho [cited. Brasília: Infologo; 2017 [cited 2017 Abr 05]. Available from: http://www3.dataprev.gov.br/aeat/.

Kearney J. Food consumption trends and drivers. Philosophical Transactions Biolog of The Royal Society 2010;365:2793-2807.

Lakatos EM, Marconi MA. Técnicas de pesquisa. $5^{\text {th }}$ ed. São Paulo: Atlas; 2003.

Linder M. Playing chicken with people: The occupational safety and health consequences of throughput uber alles. International Journal of Health Services 1995;(25):634-669.

Lipscomb HJ, Epling CA, Pompeii LA, Dement JM. Musculoskeletal symptoms among poultry processing workers and a community comparison group: Black women in low-wage jobs in the rural south. American Journal of Industrial Medicine 2007;(50):327-338.
Marra GC, Souza LH, Cardoso TAO. Biossegurança no trabalho em frigoríficos: da margem do lucro à margem da segurança. Ciência \& Saúde Coletiva 2013;11(18):3259-3271.

Musolin K, Ramsey JG, Wassell JT, Hard DL, Mueller C. Health hazard evaluation report: evaluation of musculoskeletal disorders and traumatic injuries among employees at a poultry processing plant. Centers for Disease Control and Prevention. National Institute for Occupational Safety and Health 2014;(125):1-45

NR36 - Segurança e Saúde no Trabalho em Empresas de Abate e Processamento de Carnes e Derivados. In: Manuais de legislação atlas. Segurança e medicina do trabalho. 73 ${ }^{\text {th }}$ ed. São Paulo: Atlas; 2014.

Pegatin T. O. Estratégia para análise de efeitos dos curtos tempos de ciclo na funcionalidade de membros superiores em trabalhadores de atividades semi-automatizadas [dissertação]. Ponta Grossa (PR): Universidade Tecnológica Federal do Paraná; 2009.

Reardon T, Farina $\mathrm{E}$. The rise of private food quality and safety standards: Illustrations from Brazil. International Food and Agribusiness Management Association 2010;(4):413-421.

Reason J. Combating omission errors through task analysis and good reminders. Quality Safety Health Care 2002;(11):40-44

Reason J. Human error. Cambridge: Cambridge University Press; 1990.

Reis PF. O trabalho repetitivo em frigorífico: utilização da estesiometria da mão como proposta para avaliação dos níveis de LER/DORT nas síndromes compressivas dos membros superiores [tese]. Florianópolis (SC): Universidade Federal de Santa Catarina; 2012.

Santana NIL, Rodrigues GRS. Acidentes de trabalho em frigoríficos. Cientefico 2014;29(14):75-92.

Schulz MR, Grzywacz JG, Chen H, Mora DC, Arcury TA, Marin AJ, et al. Upper body musculoskeletal symptoms of Latino poultry processing workers and a comparison group of Latino manual workers. American Journal of Industrial Medicine 2012;(56):197-205.

Stearns PN, Schwartz DR, Beyer BK. World history: tradition and new direction. New York: Prentice Hall; 1999.

Tappin DC, Bentley TA, Vitalis A. The role of contextual factors for musculoskeletal disordes in the New Zealand meat processing industry. Journal Ergonomics 2008;10(51):1576-1593.

Thomsen JF, Mikkelsen S, Andersen JH, Fallentin N, Loft IP, Frost P, et al. Risk factors for hand-wrist disorders in repetitive work. Journal Occupational and Environmental Medicine 2007;(64):527-533.

Vasconcellos MC, Pignatti MG, Pignati WA. Emprego e acidentes de trabalho na indústria frigorífica em áreas de expansão do agronegócio, Mato Grosso, Brasil. Saúde e Sociedade 2009;4(18):662-672.

Vilela RAG, Almeida IM, Mendes RWB. Da vigilância para prevenção de acidentes de trabalho: contribuição da ergonomia da atividade. Ciência \& Saúde Coletiva 2012;10(17):2817-2830.

Yin RK. Estudo de caso: planejamento e métodos. $4^{\text {th }}$ ed. Porto Alegre: Bookman; 2010. 